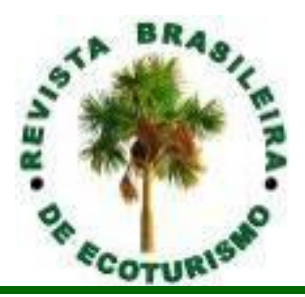

\title{
Conservation tourism as a strategy to promote the conservation of biodiversity among BRICS countries
}

\section{Turismo de conservação como estratégia para promover a conservação da biodiversidade entre os países do BRICS}

\author{
Oldemar de Oliveira Carvalho-Junior, Minal Desai
}

\begin{abstract}
This work aims to discuss tourism among BRICS members, especially between Brazil and India, considering the pandemic caused by COVID-19 and how tourism can help overcome this crisis, promoting biodiversity conservation among member countries. Historical and current data from official international sources, in Brazil and India's government, were obtained and analyzed to create an overview of the current status of tourism among BRICS countries. India represents only $15 \%$ of the total tourists who come to Brazil. In Santa Catarina, an important tourist destination in southern Brazil, in 2018, only 56 tourists came from Russia, 39 from China, 32 from India, and 25 from South Africa. As a consequence of COVID-19, tourism will likely have to reinvent itself or, at least, be aware of other windows of opportunity for its survival and growth. As a result, experiential tourism, such as conservation tourism, is expected to consolidate more strongly. Conservation tourism, an innovative proposal, can be defined as the tourism segment that uses natural and cultural heritage, through a socio-environmental research project, with the participation of ecovolunteers, promoting the social entrepreneurship of the communities involved, focused on the experience and learning in protected areas, contributing to their planning, use, sustainability, and conservation, with social responsibility. The difference between conservation tourism and ecotourism is that conservation tourism generates information, unlike ecotourism, which uses available information. This type of tourism, conservation, and community base, with research and education bias, can represent an essential agenda of approximation between the BRICS countries. The definition of a cooperation agenda can be fundamental to promote conservation tourism while helping to protect biodiversity, generating jobs, and being a source of income for the communities involved.
\end{abstract}

KEYWORDS: COVID; Tourism of Experience; Ecovolunteer; CommunityBased Tourism.

Sociedade Brasileira de Ecoturismo. Rua Dona Avelina, 225, Vila Mariana, São Paulo, SP - Brasil.351 E-mail: zneiman@gmail.com; Tel. (55-11) 99195-7685. 
RESUMO: Este trabalho tem como objetivo discutir o turismo entre os membros do BRICS, especialmente entre Brasil e Índia, considerando a pandemia causada pela COVID-19 e como o turismo pode ajudar a superar essa crise, promovendo a conservação da biodiversidade entre os países membros. Dados históricos e atuais de fontes internacionais oficiais, do governo do Brasil e da Índia, foram obtidos e analisados para criar uma visão geral da situação atual do turismo entre os países do BRICS. A Índia representa apenas $15 \%$ do total de turistas que vêm ao Brasil. Em Santa Catarina, importante destino turístico do sul do Brasil, em 2018, vieram apenas 56 turistas da Rússia, 39 da China, 32 da Índia e 25 da África do Sul. Como consequência do COVID-19, o turismo provavelmente terá que se reinventar ou, pelo menos, estar ciente de outras janelas de oportunidade para sua sobrevivência e crescimento. Como resultado, espera-se que o turismo de experiência, como o turismo de conservação, se consolide mais fortemente. O turismo de conservação, uma proposta inovadora, pode ser definido como o segmento turístico que utiliza o patrimônio natural e cultural, por meio de um projeto de pesquisa socioambiental, com a participação de ecovoluntários, promovendo o empreendedorismo social das comunidades envolvidas, com foco na experiência e no aprendizado em áreas protegidas, contribuindo para seu planejamento, uso, sustentabilidade e conservação, com responsabilidade social. A diferença entre o turismo de conservação e o ecoturismo é que o turismo de conservação gera informações, ao contrário do ecoturismo, que usa as informações disponíveis. Esse tipo de turismo, de conservação e de base comunitária, com viés de pesquisa e educação, pode representar uma agenda essencial de aproximação entre os países do BRICS. A definição de uma agenda de cooperação pode ser fundamental para promover o turismo de conservação ao mesmo tempo em que ajuda a proteger a biodiversidade, gera empregos e é fonte de renda para as comunidades envolvidas.

PALAVRAS CHAVE: COVID; Turismo de Experiência; Ecovoluntário; Turismo de Base Comunitária.

\section{Introduction}

BRIC is an acronym used to refer to Brazil, Russia, India, China, created in 2001, with the addition of South Africa in 2011, changing to BRICS. It is the meeting of five emerging countries representing a significant portion of the population and goods produced on a global scale: $42 \%$ of the world population, $23 \%$ of world GDP, $30 \%$ of global territory, and $18 \%$ of world trade. In 2018, the total population of the BRICS was 3.18 billion: China, with 1.42 billion, followed by India with 1.35 billion, Brazil with 211 million, Russia with 144 million, and South Africa with 57 million (ALVES, 2019).

Thus gathered, the BRICS member countries seek to occupy a place of greater relevance and influence on the world stage. Among the goals established by the BRICS is the construction of a multisectoral cooperation agenda among its members in science and technology, trade, energy, health, education, innovation, and the fight against organized crime. An example of this movement is a 2015 meeting to discuss CSS (South-South Cooperation), resulting in debates with representatives from South Africa, Brazil, China, Colombia, India, Indonesia, Kenya, Malawi, Mexico, Mozambique, Nigeria, Turkey, Uganda, and Zimbabwe. Discussions centered on assessing CSS's 
principles and aligning them with the SDGs on the United Nations 2030 agenda (RIZZO, 2019).

The issue of institutionalizing the cooperation process may be of fundamental importance for defining a specific international cooperation agenda, potentially facilitating access to data, as well as the creation of integrated projects of common interest. This approach includes greater cooperation in Science and Technology (S\&T), although still very incipient (LINS, 2019). This fact is made explicit on the occasion of the VIII BRICS Summit of 2016 in Goa, India, with India and Brazil declared intentions for more significant bilateral trade (LINS, 2019).

A bilateral cooperation agreement was recently signed between India and Brazil at the 2nd Meeting of the Mixed Brazil-India Commission for Cooperation in Science and Technology, held in Brasília in June 2018. More recently, on 26 January 2020, the Action Plan to Strengthen the Strategic Partnership between Brazil and India included broad discussions on topics such as trade, commerce, environment, and technical cooperation, indicating great potential for growth in bilateral understandings between Brazil and India (BARBOSA, 2019).

In Goa, for example, the official language is Konkani, but a small portion of the population still speaks Portuguese. Goa was a Portuguese domain for more than 400 years until liberation by the Indian army in 1961. Although few actions beyond agreements with good intentions have been made in this regard to date, Goa has several outstanding Institutes such as Goa University and Dhempe College of Arts \& Science, where it is possible to develop research partnerships.

Tourism has traditionally occupied a marginal place on the BRICS agenda. With the creation of the New Development Bank (NDB) on July 15, 2014, tourism has gained more attention as a strategy to promote access to credit by public managers and companies. In the Brazilian government, discussions have been conducted by Prodetur, with the support of the National Bank for Economic and Social Development (BNDES), the Development Bank of Latin America (CAF), and the General Tourism Fund (Fungetur), in search of financial support for tourism projects.

In India, the tourism industry has been one of the largest contributors to India's GDP in recent years, increasing from a share of $6.70 \%$ in 2017 to $9.20 \%$ in 2018. Over recent years, the Government of India has taken various supportive measures and has focused on making India a global tourism destination. The World Travel and Tourism Council ("WTTC") 2020 reported tourism generated 39,821 million jobs in India in 2019, representing $8.0 \%$ of total employment that year.

Ecotourism in India is a thriving industry as it is one of the most diverse lands on the globe. The country has four biodiversity hotspots of the world, the Himalayas, the Western Ghats, the Indo-Burma region, and the Sundaland. The country has wildlife sanctuaries, national parks, forests, mountains, snow-covered hills, deserts, sacred groves, wetlands, and mangrove forest, with its diverse flora and fauna. These are important 
environmental assets for the development of tourism conservation and research projects associated with ecovolunteerism.

\section{Tourism and COVID-19}

Financial support for tourism is even more essential in the current situation with the advent of the pandemic caused by COVID-19. For example, in Brazil, tourism is expected to suffer a sharp drop in the 2020-21 tourist season, the result of the economic crisis caused by the coronavirus. A study by the Getúlio Vargas Foundation (FGV, 2020) indicates Gross Domestic Product (GDP) will likely fall to US $\$ 31$ billion in 2020, a 38.9\% reduction in revenues compared to the previous year, at US $\$ 50.3$ billion.

Despite the uncertainties of the impact Covid-19, a minimum of one year is foreseen for the recovery of tourist activities in Brazil. One of the current discussions concerns the adopted tourism models, due to the requirements of a smaller number of people per square meter, avoiding agglomerations. In this regard, the traditional mass tourism should be the most impacted, making room for other types of tourism. Currently, tourism contributes to $3.71 \%$ of the country's GDP (IBGE, 2019). However, this value reflects mass tourism, which over-crowds' beaches, hotels, and restaurants, causing vast agglomerations and intense impacts on marine and freshwater quality. When looking at this side, it is observed that tourism has a role beyond the economic and financial. For example, the environmental issue has been neglected, and the negative impacts caused by mass tourism are ignored by decision-makers and public policymakers (BACAL et al., 2007).

In India, 1,05,57,976 foreign tourist arrived in 2018 and 1,09,30,355 in 2019. In 2020 from January to March, 24,62,244 tourists arrived (INDIA TOURISM STATISTICS 2019 - GET COMPLETE INFORMATION, 2020). COVID 19 lockdown in the country in March 2020 has adversely impacted the tourism industry. As in Brazil, tourism in India has witnessed a significant decline during this time. India's government has a crucial role to play in the revival and growth of the tourism industry, and immediate relief measures are to be taken to minimize the impact of COVID-19 on the tourism industry.

\section{The importance of integration between peoples and the role of tourism in strengthening sustainable development and conservation of biodiversity}

Tourism is also essential as an auxiliary tool in the integration between peoples, both within a country and between countries (WAHAB, 1991). It is also a form of interaction between different cultures while promoting economic development, the management and preservation of natural and historical heritage, generating jobs and training of specialized labor, and promoting community-based entrepreneurship (NOGUEIRA, 1987; CARVALHO JUNIOR et al., 2009; CARVALHO JUNIOR; SPERB, 2011; SANTOS, 2013; CARVALHO JUNIOR; BIROLO, 2019). This approach is what characterizes, in part, the conservation tourism proposal. 
Conservation tourism can be defined as the "tourism segment that uses natural and cultural heritage, through a socio-environmental research project, with the participation of ecovolunteers, promoting the social entrepreneurship of the communities involved, focused on the experience and learning in protected areas, contributing to their planning, use, sustainability, and conservation, with social responsibility". This activity is necessarily associated with a research project, with the participation of ecovolunteers, and has strong institutional support from specialized national and international agencies (CARVALHO JUNIOR; BIROLO, 2019). Therefore, it reflects a democratic effort in which all parties are benefited and based on a socio-environmental cause.

Currently, in Brazil, the only initiative of a conservation tourism project is the Projeto Lontra of the Instituto Ekko Brasil, located on the Island of Santa Catarina (Florianópolis), State of Santa Catarina, south of Brazil. The Project implemented an Ecovolunteer Program in 2002, and today receives ecovolunteers from several countries, in particular France and the United States. The Project has the support of several international agencies in Europe and the United States, linked to sustainable and responsible tourism. The ecovolunteer selects a project on the agency's website that helps it to plan and organize the trip. An ecovolunteer usually travel alone or with a friend.

Multidisciplinary tourism, such as conservation, aimed at lone travelers or small groups, requires more significant support and action from the government to prosper. For example, in the case of the BRICS member countries, to promote this tourism, it would be essential to increase air connections between member countries, with cheaper rates and greater agility in granting visas.

In general, public-policies are more concerned with mass tourism buses and chartered planes dumping concentrations of persons on specific tourist targets - often, an approach that brings little benefit to local communities. In this case, there is practically no interaction between tourists and local culture, cuisine, and the natural environment. With the pandemic, this type of tourism could be severely compromised. Those who can benefit from this situation are destinations that work with a small number of customers and have greater ethical and moral value. Figure 1 shows the variation in the number of tourists in Brazil, China, India, Russia, and South Africa, over the years. 

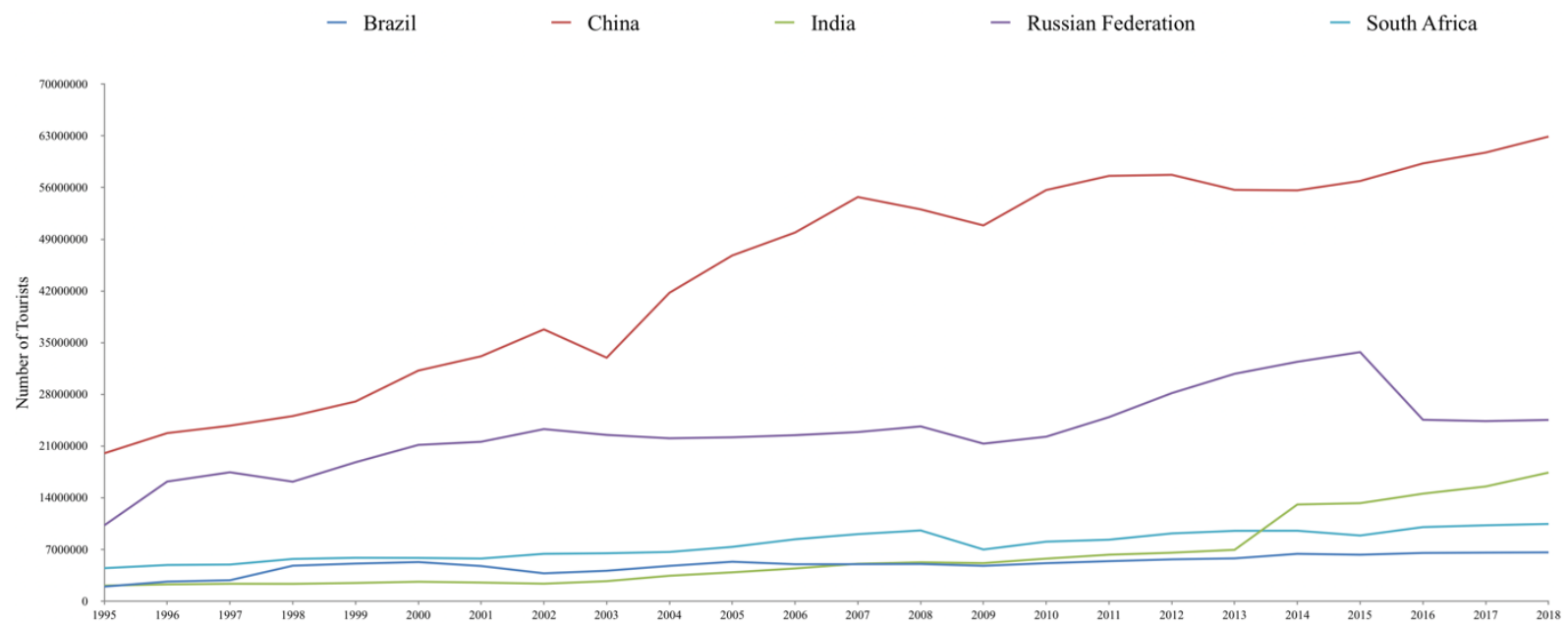

Figure 1: Number of tourists in the BRICS countries over the years, from 1995 to 2018 (THE WORLD BANK, 2020). Source: elaborated by the authors (2021).

As can be seen in Figure 1, Brazil is last in terms of number of tourist arrivals, with less than 7 million visitors, surpassed by South Africa and India. It is worth mentioning the increase in tourists in India from 2013, reaching $17,423,000$ visitors in 2018, threatening Russia's second position with $24,551.00$ in the same year. China solidly occupies the first position of arrival of tourists among the BRICS countries, with almost 63 million tourists in 2018.

Brazil is also heavily dependent upon from a single country. In 2018, Brazil received $6,621,376$ tourists, the vast majority are from Argentina $(2,498,483)$, representing $43 \%$ of the total followed by the United States $(9 \%)$, Chile $(7 \%)$, Paraguay and Uruguay (6\%) (Figure 2).

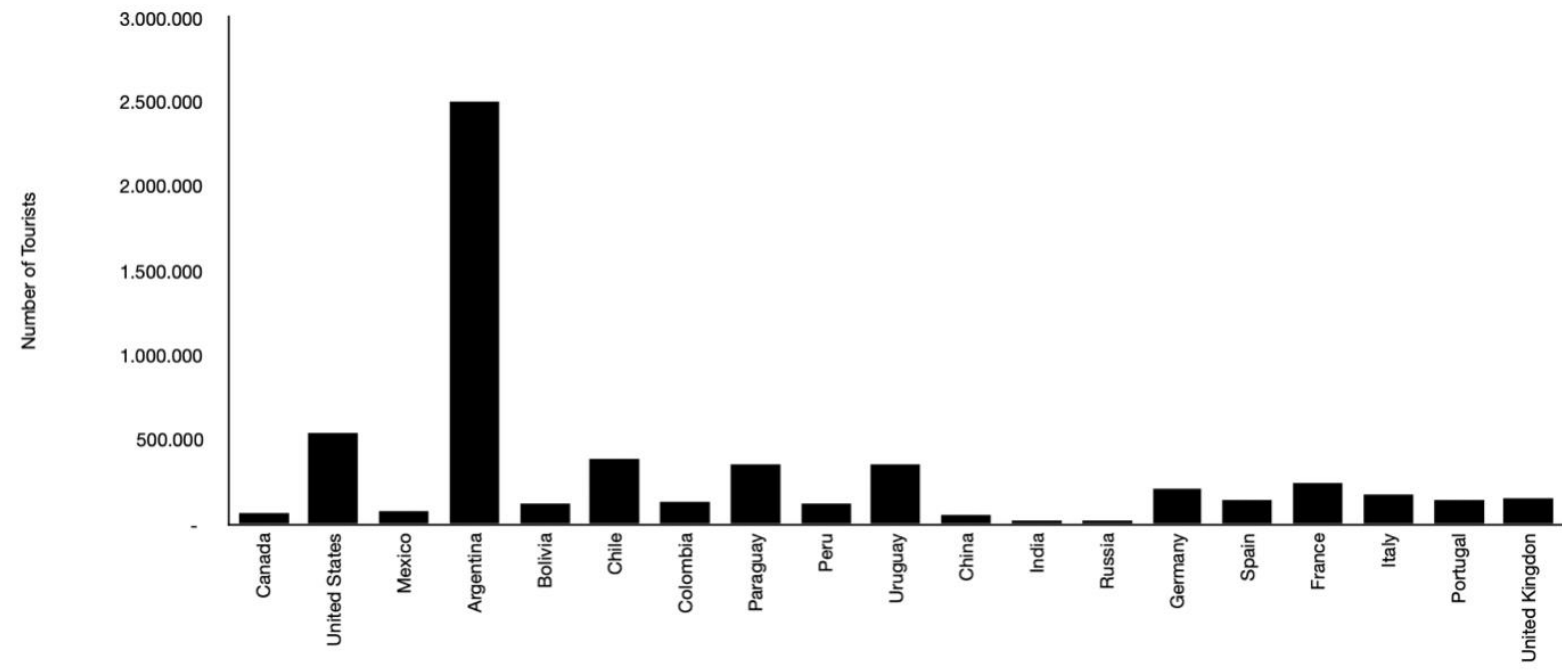

Figure 2: Number of tourists in Brazil in 2018 by countries (ANUÁRIO ESTATÍSTICO DE TURISMO, 2019). Source: elaborated by the authors (2021). 
In 2018, tourists from South America made up 63\% of the total tourists visiting Brazil, followed by Europe (23\%), North America (11\%), and Asia (4\%). 1,460,740 tourists came from Europe, mostly France 238,345 (22\%), followed by Germany (209 039) (19\%), Italy (175 763) (16\%), United Kingdom (154 586) (14\%), Spain (147 159) (14\%), and Portugal (145 816) (13\%) (Figure $3 a$ and $3 b$ ).

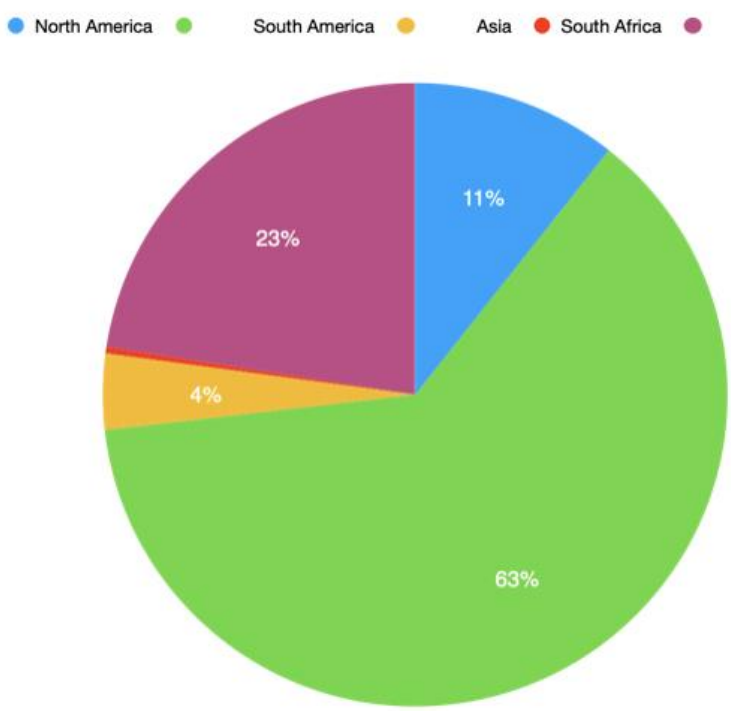

(a)
Europe Germany Spain France Italy Portugal United Kingdon

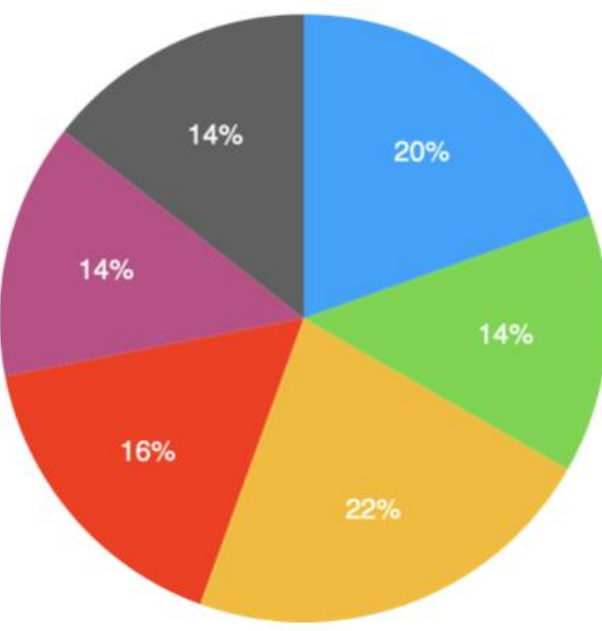

(b)

Figure 3: (a) Percentage of tourists who visited Brazil in 2018 from North America, South America, Asia, and Europe. (b) Percentage of tourists visiting Brazil from Europe (ANUÁRIO ESTATÍSTICO DE TURISMO 2019). Source: elaborated by the authors (2021).

In Brazil, the State of Santa Catarina had 226,362 visitors in 2018 (Statistical Yearbook of Tourism, 2019). São Paulo state receives the most tourists with 2,250,994 people in 2018, followed by Rio de Janeiro with 1,293,342, and Rio Grande do Sul with 1,087,191 visitors. Santa Catarina ranks $5^{\text {th }}$ in the number of tourists.

Of the total tourists who visited the state of Santa Catarina in 2018 $(226,362), 85 \%$ come from Argentina (192,708). Looking at tourism from South America in $2018(221,888), 87 \%$ of all visitors come from Argentina at 192,708 , followed $10 \%$ from Chile $(22,954), 2 \%$ from Paraguay $(3,494), 1 \%$ from Uruguay $(1,644)$ and less than $1 \%$ from Peru (Statistical Yearbook for Tourism 2019) (Figure 4). These figures demonstrate a total dependence on Santa Catarina tourism with Argentina, worldwide, and even more so in South America. 

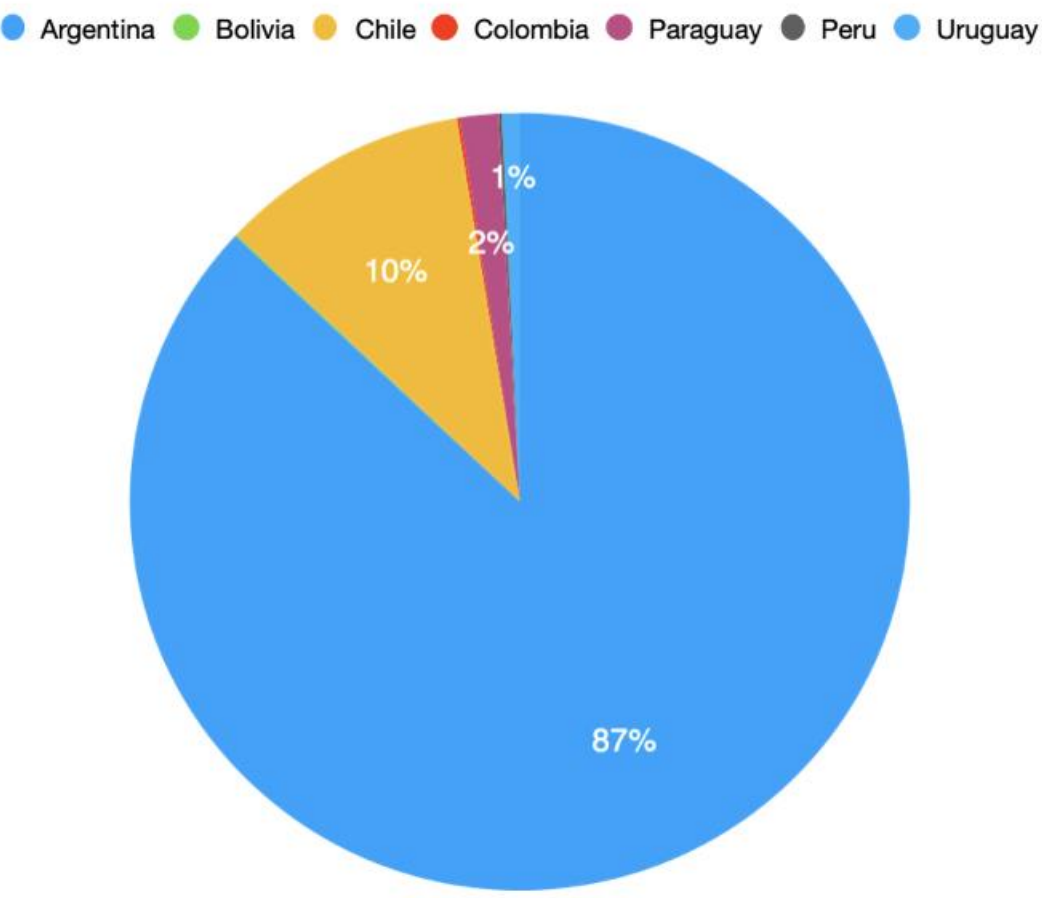

Figure 4: Presence of tourists in the State of Santa Catarina from countries in South America (ANUÁRIO ESTATíSTICO DE TURISMO 2019).

Source: elaborated by the authors (2021).

Considering other BRICS countries, the number of tourists who come to Brazil is much more modest. The Chinese appear in more significant numbers, with 56,333 tourists, followed by South Africans $(21,284)$, Russians $(19,224)$, and Indians $(16,719)$ (Figure 5).

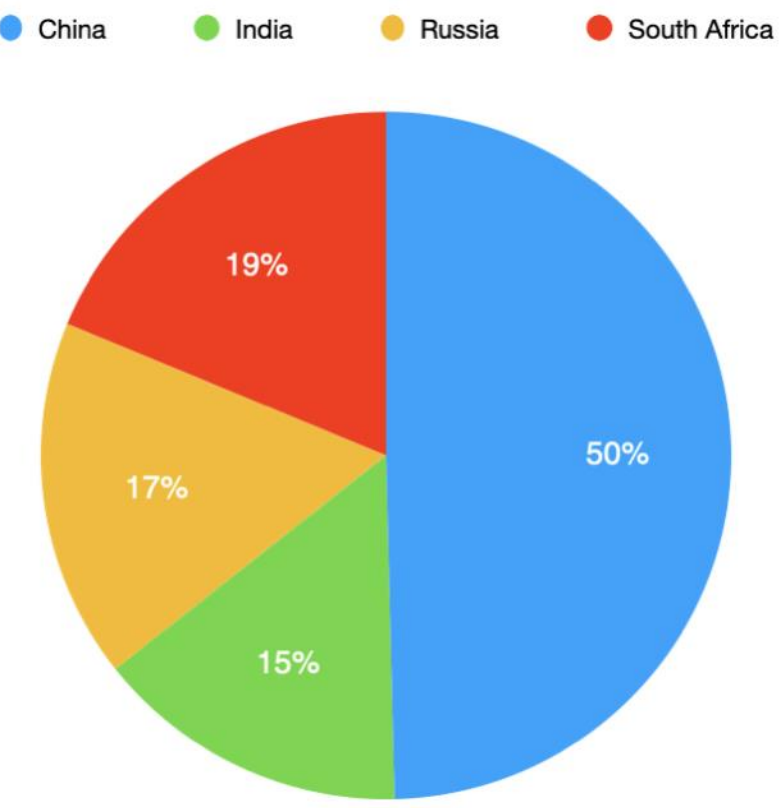

Figure 5: Presence of tourists in Brazil from countries that, together with Brazil, form the BRICS (ANUÁRIO ESTATÍSTICO DE TURISMO, 2019).

Source: elaborated by the authors (2021). 
In Santa Catarina, considering only the European community, there were 2,576 tourists in 2018, Italy 512, Spain 393, Germany 362, and France 259. In the case of the BRICS, the numbers are almost irrelevant. In 2018, only 56 tourists came from Russia to Santa Catarina, 39 from China, 32 from India, and 25 from South Africa.

In comparison, the Ecovolunteer Program of Instituto Ekko Brasil (IEB), through the Otter Project, based in Santa Catarina Island, received 120 ecovolunteers in 2018 and 133 in 2019. The resources obtained with the Program were used to develop research and the maintenance of orphaned otters in recovery at the IEB Animal Refuge.

Of the 259 French visiting Santa Catarina, 49 or nearly $20 \%$ were ecovolunteers with the Ekko Brasil/Otter Project. The segment of tourism practiced by the IEB is the Conservation Tourism, which shows that there is a potential audience that is still under-worked. It is low-impact tourism that helps in the development of research with endangered species. Its public seeks more knowledge and wants to invest in noble causes.

The bad news for Brazilian tourism does not stop there. Foreign exchange revenue Brazil occupies the 47th position in the ranking of countries, with US $\$ 5.9$ billion in 2018 . Worldwide, the total foreign exchange revenue in 2018 was US\$ 1,448 billion. Brazil represents only $0.41 \%$ of this revenue (STATISTICAL YEARBOOK OF TOURISM, 2019). Most tourists in Brazil come for leisure (58.8\%), aiming to enjoy the sun and the beach (72\%). Nature and ecotourism represent $16 \%$ of the motivation for the trip. Most are in the age group that varies from 30 to 50 years old (48\%) and higher education (45\%). The main destinations for the public who say they come for nature and ecotourism are the Pantanal, Foz do Iguaçu Falls, and the Amazon. It is worth remembering that Pantanal and Amazonia were the main news in 2020, related to deforestation and forest fire, decimating a large part of Brazilian biodiversity. For example, according to Inpe's Queimadas Program, the Pantanal had 2,856 fires over October, the highest number ever recorded for the month.

These numbers of tourists are mainly concentrated in a single month, January, reaching 1,067,389 people in 2018, followed by February with 868,482 tourists. With the sum of the two months, January and February 2018 , there are $1,935,871$ people, representing $29.2 \%$ of the total for the year. These figures, concentrated in the two months of the summer, demonstrate the strength of mass tourism that fills the beaches, bars, and restaurants of the leading Brazilian tourist destinations. This "herd" behavior can be modified with the advent of Covid-19.

On the other side, in 2018, 933,841 foreign tourists visited Goa, India, a maximum number of 183,424 arrived in December. Tourists from more than 30 countries traveled to India for recreation. Russians $(333,565)$ were the maximum number of foreign tourists that visited Goa, followed by the UK $(294,569)$. Among the other BRICS countries, 641 visitors from Brazil and 643 from South Africa toured Goa in 2018. Goa's beaches attract most tourists; however, 51,610 foreign tourists visited the four wildlife sanctuaries of Goa, and 406 of them stayed in the accommodation in and around the 
sanctuaries. 406,896 Indian tourists and 16,919 school children visited the Wildlife Sanctuaries of Goa.

Slow travel tends to occupy more space in the search for tourist destinations (GOLDEN, 2019). This trip assumes that the longer the person stays in the same place, the more benefits it gets, such as better-quality rest, in addition to presenting a more sustainable and rewarding behavior for the environment. However, this type of tourism can still be considered incipient, with a limited offer in the market to those who are interested.

Therefore, it is necessary to plan and develop differentiated tourism, which contemplates a public with a different profile from that of mass tourism. To this end, companies must also have to adapt to this new reality. It is not just about thinking that the mass tourism audience is going to change behavior but recognizing that another audience is outside the official statistics. This public can bring more benefits to traditional communities, with greater respect and appreciation of environmental assets.

It is about having a more careful look at an audience that has always been there, but it was ignored because it presents a small return to businesses and agencies focused on mass tourism. Companies will be required to review their business plan and adapt to a new situation, where commitment to the environmental cause and social responsibility should occupy a more prominent place in the economy.

\section{Can conservation tourism be an alternative for strengthening integration between countries in joint actions for the conservation of biodiversity?}

Tourism has become more relevant in Brazil since 1990, with the exchange of foreign debt papers for tourist actions in the country, thus attracting the capital of large hotel chains (GODOI and AMARAL, 2019). At that time, adventure tourism and ecotourism also appeared, but basically by private initiative, without a specific public policy, and still relegated to a secondary role within national tourism plans (GODOI and AMARAL, 2019). On the other hand, the private sector's participation in ecotourism meets the requirements of the National Tourism Policy, which is to promote "a development that is democratic, participatory, decentralized and guided by structured competitive strategies."

In general, public policies have tourism as a generator of economic and social development. However, in practice, tourism is planned and presented as a commodity, the result of a merely developmental vision (CONCEIÇÃO, 2020). It can be said that tourism still lacks legal instruments that consider the protection of environmental resources and the communities involved (ONÓRIO; ROCHA, 2020).

Currently, experience tourism represents a type of tourism alternative to mass tourism. Experiential tourism has developed mainly in areas with a strong cultural tradition with the immigrant roots of, for example, Germans, Italians, and Azoreans (SILVA; TRENTIN, 2019). Silva and Trentin (2019), argue that this tourism establishes a useful link between the visitor who 
acquires a positive experience and the provider who can share their culture. In this regard, the state of Santa Catarina, in Brazil, has a strong potential for growth, such as the Santa Catarina and Rio Grande Sul wine region, which has an Italian cultural influence.

Similar to the tourism of experience, ecotourism also makes a counterpoint to mass tourism, as a strategy to enhance natural resources (CORREIA, 2019). On the other hand, Maranhão and Azevedo (2019), analyzing the Brazilian National Tourism Plan (2018-2022) (MINISTRY OF TOURISM, 2018), argue that ecotourism is not representative in the planning and management of Brazilian tourism, as generating foreign exchange and jobs. Therefore, ecotourism for public, educational, participatory, and social policy can still be considered as insignificant in Brazil.

In Brazil, there are already several agencies specialized in exotic itineraries, such as Owt Boutique Travel, Caboclos House, Turismo Experience, Girare, and Trip4U. Others in Brazil, who work with ecovolunteers and interns in socio-environmental and research projects, are Exchange do Bem, Brazil Ecojourneys, Segunda Milha, and Intern Brazil. Concerned with the sustainability of research projects and communities, these organizations seek to attract a sympathetic audience to socioenvironmental causes and the conservation of threatened species. Other agencies, outside of Brazil, committed to environmental causes are Cybelle Planète, Volunteer World, IE3Global, Global Citizen, and Secret Planet.

Tourism will need to reinvent itself, or at the very least, be aware of other windows of opportunity for its survival and growth. As a result, experience tourism should consolidate itself more strongly. Excursion-type trips, passing through several cities in a few days, should become increasingly scarce. For example, France and Germany are countries where experience tourism has become more prevalent in recent years. The idea is to focus on specific regions, with the thought of co-responsibility.

An example of environmental and social responsibility is compensation for the impact of the trip or the carbon footprints. Several airlines are already concerned about this, setting targets with customers to offset carbon emissions. For example, Lufthansa launched the Compensaid Program in 2019, a service where passengers can pay extra for the company to use sustainable fuel to reduce the impact of carbon emissions. Air New Zealand, on the other hand, allows its passengers to pay a little extra on the ticket to ensure compensation for the carbon emitted by the flight. Tourism agencies are also attentive to this movement.

Natural Habitats, for example, calculates the carbon emitted by tourists and thereby finances carbon reduction projects to balance emissions at an amount equal to that released during travel. Examples of this initiative are renewable wind energy projects in India, reforestation of native tree species in Zimbabwe, and biomass fuel-efficient cooking stoves in Rwanda to replace wood burning. Another initiative, the Ecovolunteer Program of Instituto Ekko Brasil/Otter Project, calculates each participant's carbon footprint. During the stay, this ecovolunteer helps himself plant several trees that correspond to the carbon equivalent spent on the trip. 
Currently, in Santa Catarina, the public that feeds tourism, in general, does not show concern for environmental conservation. Perhaps because public-policy for the sector is focused on mass tourism and focused on neighboring Argentina, it is a type of tourism that causes agglomerations, and the Covid-19 pandemic can severely impact that.

\section{The Otter Project Ecovolunteer Program}

An initiative that provides an alternative to mass tourism in Santa Catarina is the Ecovolunteer Program of the Ekko Brazil Institute/Otter Project, which shows that diversification, such as the conservation of tourism, is possible. In a planned way and included within governmental public policies, this type of tourism can attract another type of public, more concerned with environmental conservation. At the same time, it contributes to the sustainability of community-based conservation research projects. This public does not seek large urban centers and avoids places with much movement. In this case, the main focus is to contribute to a noble cause and gain more excellent knowledge, which may well represent post-pandemic tourism with biodiversity conservation.

The Ecovolunteer Program of the Otter Project has a partner network of agencies in Europe and the United States. These agencies share the same concern with the conservation of the environment and biodiversity, promoting the participation of ecovolunteers in the various projects offered. Through the Otter Project, for example, in southern Brazil, Santa Catarina Island is advertised in the leading responsible tourism agencies in Brazil, Europe, and the United States. Most ecovolunteers who come to the Otter Project also go to Foz do Iguaçu to visit the falls, returning to the Project to complete their experience in Brazil. They could also be going to Itaimbezinho Canyon, Serra do Rio do Rasto, or São Joaquim Park, other less known destinations. However, there are no dissemination strategies that reach this audience. Regardless, the ecovolunteer who comes to the Otter Project can visit several biomes where the research is carried out and contact the communities present there.

Through the Ecovolunteer Program, research carried out by Instituto Ekko Brasil covered 114,774.12 hectares in the 2018-2019 biennium. There were several microbasins within the Atlantic Forest, and Pantanal biome, including the Environmental Protection Area (APA) of Baleia Franca (SC), the Natural Monument (MONA) of Lagoa do Peri (SC), and the Ecological Station (ESEC) of Taiamã (MT). The total public reached was 54,374 people, and four species targeted for direct actions: the Lontra longicaudis (neotropical otter) - Almost globally threatened (NT) and Vulnerable (VU) in the Atlantic Forest, the Pteronura brasiliensis (giant otter) - Threatened (EN), Galictis cuja (ferret) - Little Concern at a global level (LC) and Deficient Data (DD) in Brazil, and Eira barbara (irara) - Little Concern at a global level (LC) and Deficient Data (DD) in Brazil (IUCN, 2020).

With the Ecovolunteer Program alone, the IEB obtained resources used to maintain research, social mobilization, environmental education 
actions, and the maintenance and functioning of the Animal Refuge where orphans of the Mustelidae family are recovered. Thus, the knowledge produced is always used to modify an adverse reality, with researchers' active involvement and institutional support. Conservation tourism's proposal is based on sustainability and information generation. These aspects can be used to assist in the planning and management of natural resources, in addition to helping to generate indirect jobs for local actors.

Therefore, research at the Otter Project is of transcendental importance because it is the main generator of information. It is not by chance that conservation tourism has as the central requirement the existence of a research project, in which the ecovolunteer participates. From 2018 to 2019, with the Otter Project alone, four technical notes, ten scientific papers, and three research programs were published, and two technical courses were conducted. The difference between conservation tourism and ecotourism is that conservation tourism generates information, unlike ecotourism, which uses available information. This information should be made available to different audiences, academics, schoolchildren, laypeople, and decision-makers. At the same time, it must lead to changes in adverse realities, which bring benefits to society while subsidizing sustainable development with the protection of biodiversity.

It is essential to highlight the strategic planning of the research with the 2030 Agenda for Sustainable Development. In the case of Instituto Ekko Brasil, the SDGs permeate all developed projects, such as the Otter Project. An example is SDG4 - Quality Education, SDG6 - Drinking Water and Sanitation, SDG7 - Accessible and Clean Energy, SDG8 - Decent Work and Economic Growth, SDG11 - Sustainable Cities and Communities, SDG12 Responsible Consumption and Production, SDG13 - Action Against Global Climate Change, SDG14 - Life in Water, SDG15 - Terrestrial Life, SDG17 Partnerships and Implementation Means. In this way, the Otter Project contributes to the agreement signed between the Brazilian Government and the United Nations Development Program (UNDP), including 10 of the 17 Sustainable Development Goals (SDGs).

According to the UN (World Resources Institute 2019), 68\% of the population will live in cities in 2050. In Brazil, $84.72 \%$ of the population lives in urban areas (IBGE, 2015). The distancing of people from the natural environment is striking. This distancing contributes to the creation of Integral Conservation Units, which exclude people from the process of biodiversity conservation. Also, social fragmentation in cities, as a result of the neighborhood effect, promotes the gap between rich and poor.

The Center for Visitation and Environmental Education of the Ekko Brasil Institute is a space poised to receive schools and visitors in general, to give courses and lectures, promoting the conservation of biodiversity and water with the otter as a symbol species. From 2018 to 2019, it received 174 educational institutions, of which 97 were public schools and 77 private schools, totaling more than 5,000 students. The months with the highest number of visiting schools were April, May, June, August, September, October, and November, coinciding with the school calendar. January, 
February, March, and December represented the months with the lowest number of visiting schools, reflecting the academic school recess in Brazil (Figures 6 and 7).

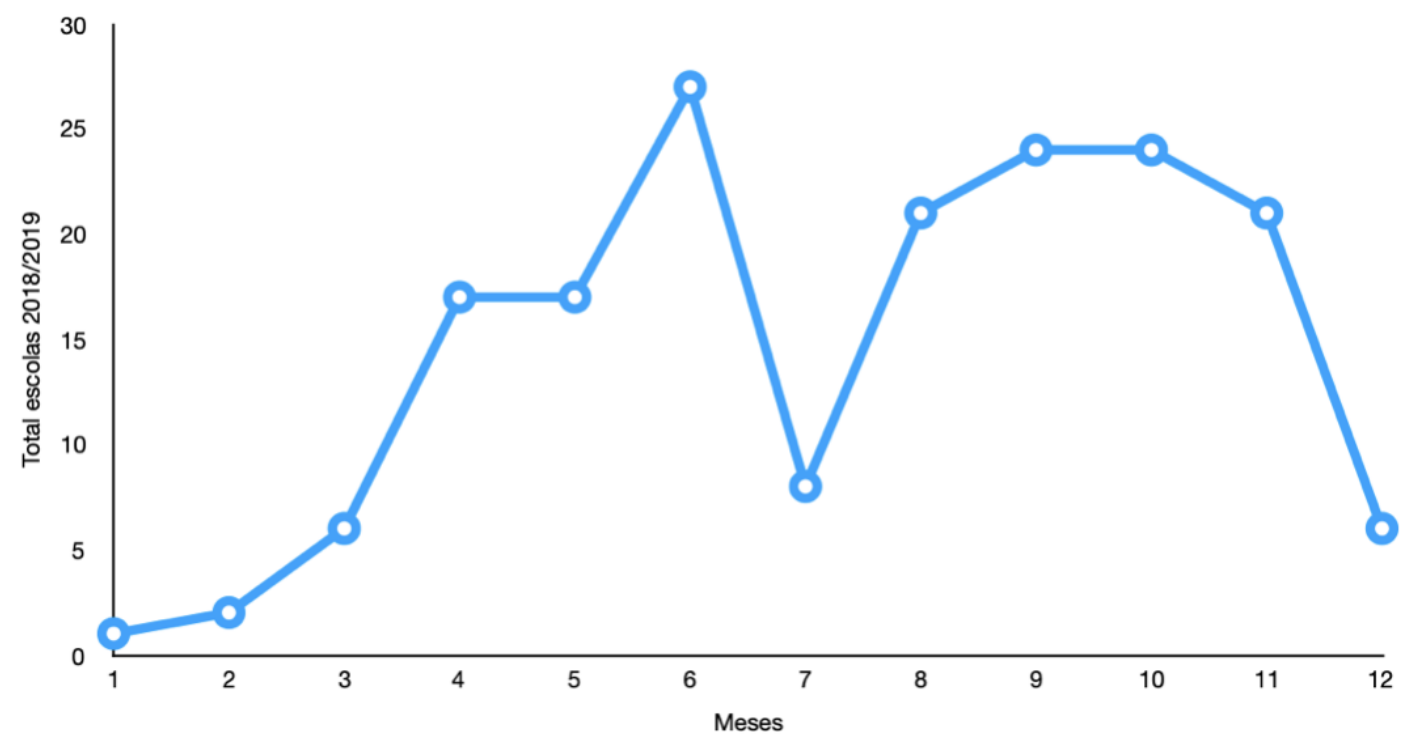

Figure 6: Distribution of school visits over the months for 2018 and 2019 at the Visitation and Environmental Education Center of the Ekko Brasil Institute in Florianópolis, SC. In total, 174 schools visited the Otter Project in the 2018-2019 biennium. Source: elaborated by the authors (2021).
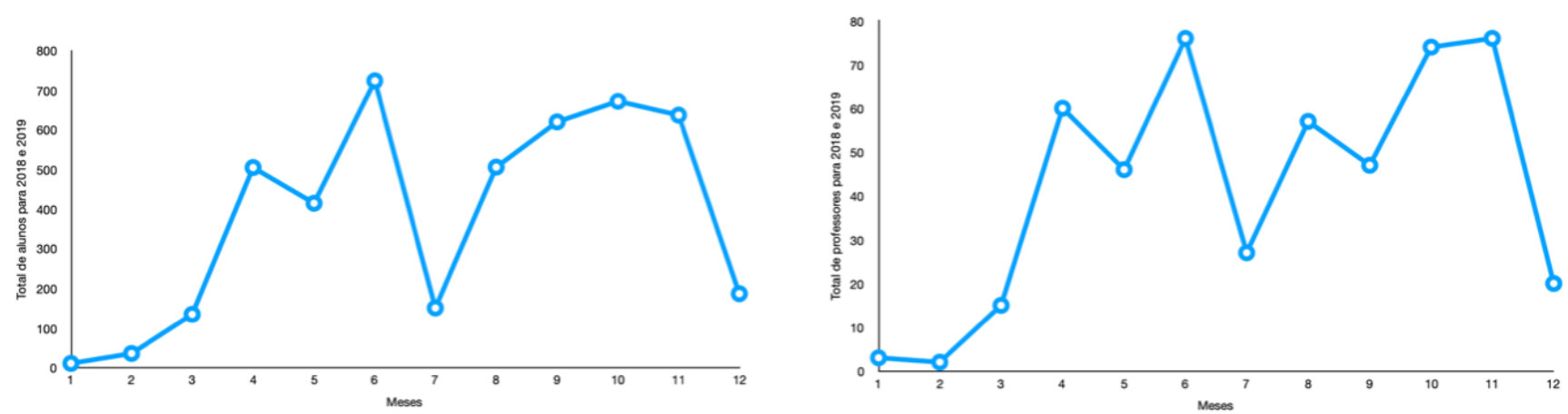

Figure 7: Distribution of the number of students and teachers over the months for 2018 and 2019. In total, 4,599 students and 503 teachers visited the OtterProject in the 2018-2019 biennium. Source: elaborated by the authors (2021).

In addition to the Visitation Center, Instituto Ekko Brasil has a space called the Integrated Nucleus of Biodiversity Projects, aiming to aggregate other projects to share experiences and improve conservation work. The Integrated Nucleus seeks to maximize the efforts of both research specialists and financial resources to strengthen the projects created and continue the programs developed.

One of the strategies adopted by the Nucleus is the economic evaluation of ecosystem environmental assets, inserted within the circular economy and social economy. The circular economy aims to reduce, reuse, recover and recycle materials and energy, and advocate replacing the linear economy's end-of-life concept with new circular flows of reuse, restoration, 
and renovation. On the other hand, the social economy represents private economic activities, which are not just for profit, and share their objectives with the public sector.

\section{Final Considerations}

The experience with the Ekko Brasil Institute's Ecovolunteer Program shows networking is fundamental to a project's success. This conservation tourism with research and education bias can represent an essential approximation agenda between the BRICS countries. Brazil and India represent an example of how tourism is little used to promote a more generous friendship and peace between peoples and opportunities to generate jobs and promote greater awareness for the conservation of biodiversity. The numbers of tourists involved among the BRICS member countries are insignificant given the nations' size. There is an urgent need to define public policies aimed at tourism, which facilitate people's movement, with more accessibly priced plane tickets, enabling the creation of small businesses aimed at the sustainability of biodiversity conservation projects. With non-governmental and governmental agencies' participation, the joint tourism agenda can promote biodiversity conservation, knowledge, and culture, bringing people together.

\section{References}

ALVES, J. A população do grupo BRICS. EcoDebate, N. 3175, 2019.

ASHOK, S., BEHERA, M.D.; TEWARI, H.R. Evaluating the applicability of ESM (Ecotourism Sustainability Maximization) model to assess, monitor, and manage the ecotourism sustainability in mountain ecosystem (Mt. Kangchendzonga Base Camp Trek, India). Environ Monit Assess, v.191, n.801, 2019.

BACAL, S.S, MELO, A.J.S.M, WIDMER, G.M., PEREIRA, R.S. Turismo sustentável no Brasil: utopia ou possibilidade? Revista Gerenciais, São Paulo, v. 6, n. 2, p. 175-181, 2007.

BARBOSA, P.H.B. Challenges and Opportunities in the Brazil-Asia Relationship in the Perspective of Young Diplomats. Funag: Brasilia, 2019.

CARVALHO JUNIOR, O.; RODRIGUES, R.; SCOTON, G. Sistema de Informação Geográfico (SIG) como ferramenta auxiliar para o planejamento e gestão do turismo na Bacia Hidrográfica do Rio Itajaí-Açú (Santa Catarina). Caderno Virtual de Turismo, v.9, n.1, pp.63-87, 2009.

CARVALHO JUNIOR O, SPERB RM. A bacia catarinense do Rio Uruguai e o turismo de conservação como ferramenta ao desenvolvimento sustentável regional. Revista Brasileira de Ecoturismo, v.5, n.1, pp.67-86, 2011.

CARVALHO JUNIOR, O., BIROLO, A.B. Conservation Tourism for the Sustainability of Coastal Areas. Case Study: Otter Project. Revista Costas, v.1, n.1, pp.87-106, 2019. 
CONCEIÇÃO, R.A.M. Turismofobia e políticas públicas em turismo. Revista Turismo \& Cidades, v.2, n.3, pp.150-68, 2020.

CORREIA, C.B.S. Evolução do ecoturismo no Brasil: de 1993 a 2003. Trabalho de Conclusão de Curso de especialização, Universidade de Brasília, 2019. https://doi.org/10.26512/2003.05.TCC.289.

FGV. Impacto econômico do Covid-19: Propostas para o turismo brasileiro, FGV Projetos, Rio de Janeiro, 2020.

GODOI, R.C.; AMARAL, S.C.F. O Reflexo do Projeto Neoliberal nas Políticas Públicas em Turismo e Turismo de Aventura no Brasil. LICERE - Revista do Programa de Pós-graduação Interdisciplinar em Estudos do Lazer, v.22, n.4, pp.489-518, 2019.

GOLDEN, F. Década de 2020 traz novas tendências para viagens. Exame, 2019.

HONÓRIO, I.C.; ROCHA, I.O. Políticas Públicas de Turismo na Legislação Federal e do Estado de Santa Catarina. Revista Brasileira de Ecoturismo, v.13, n.2, 2020.

INDIA TOURISM STATISTICS 2019 - Get Complete Information, 2020. Blink Visa. 2019. URL https://blinkvisa.com/blog/india-tourism-statistics-2019/ (accessed 12.8.20).

IUCN, The IUCN Red List of Threatened Species [WWW Document]. IUCN Red List of Threatened Species, 2020. URL: https://www.iucnredlist.org/en (accessed 12.8.20).

LEFEBVRE H. O Direito à Cidade. São Paulo, Centauro, 2001.

LINS, H.N. Interações entre o Brasil e a Índia no alvorecer do século 21. Revista de Economia, v.38, n*66, 2019.

MARANHÃO, C.H.S.; AZEVEDO, F.F. A Representatividade do Ecoturismo para a gestão pública do turismo no Brasil: uma análise do Plano Nacional de Turismo 2018-2022". Revista Brasileira de Ecoturismo, v.12, n·1, 2019.

MINISTÉRIO DO TURISMO. Plano Nacional de Turismo 2018-2022. Brasilia: Ministério do Turismo, 2018.

NOGUEIRA M. Papel do Turismo no Desenvolvimento Econômico e Social do Brasil, Rev. Adm. publ., v.21, n.2, pp.37-54, 1987.

RECEITA FEDERAL. Ministério da Economia. Relações entre a Índia e o Brasil colonial. Disponível em: http://www.receita.fazenda.gov.br/historico/srf/historia/HistFazenBrasillndia.h tm. Acessado 18 de agosto de 2020.

RIZZO, A.D.G. Avaliação da cooperação Sul-Sul : uma análise comparada das perspectivas de avaliação do Brasil, Índia e África do Sul, 2019. Disponível em: http://repositorio.ipea.gov.br/handle/11058/9539, acessiado em 20 de novembro de 2020.

SILVA, E.M.C.; TRENTIN, F. Turismo de Experiência: L 'Arte Ceccato Vila Flores". Caderno Virtual de Turismo, v.18, n.3, 2019. 
THE WORLD BANK, n.d. World Bank Open Data | Data [WWW Document]. data.worldbank.org. URL https://data.worldbank.org/, (accessed 12.20.20). WORLD RESOURCES INSTITUTE Creating a Sustainable Food Future. World Resources Institute, Washington, 2019.

Oldemar de Oliveira Carvalho-Junior: Instituto Ekko Brasil, Florianópolis, SC, Brasil.

E-mail: ocjunior@ekkobrasil.org.br

Link para o currículo Lattes: http://lattes.cnpq.br/6092576258994833

Minal Desai: Department of Zoology, Goa University, India.

E-mail:minal.desai@unigoa.ac.in

Data de submissão: 11 de janeiro de 2021

Data de recebimento de correções: 19 de janeiro de 2021

Data do aceite: 19 de março de 2021

Avaliado anonimamente 